KONSTRUKTIVISME, Vol. 10, No. 1, Januari 2018

p-ISSN: 1979-9438; e-ISSN: 2442-2355

FKIP Universitas Islam Balitar, Blitar

Http://konstruktivisme.unisbablitar.ejournal.web.id; Email: konunisba@gmail.com

\title{
PENGARUH PENDEKATAN KONTEKSTUAL BERBANTUAN THINKING MAP TERHADAP PENGUASAAN KONSEP TEORI GRAF DITINJAU DARI KEMAMPUAN PEMECAHAN MASALAH
}

\author{
Filda Febrinita ${ }^{[1]}$, Wahyu Dwi Puspitasari ${ }^{[2]}$ \\ Program Studi Teknik Informatika \\ Fakultas Teknologi Informasi \\ Universitas Islam Balitar Blitar \\ Jl. Majapahit No. 4 Blitar \\ febrinitafilda80@gmail.com
}

\section{ABSTRAK}

Penerapan Teori Graf banyak ditemui dalam aktivitas kehidupan seharihari sehingga mahasiswa pun dituntut untuk mampu mengkaitkan teori yang dipelajari dengan lingkungan atau kejadian sekitar. Pembelajaran dengan pendekatan kontekstual merupakan konsep belajar yang dapat membantu mahasiswa untuk menghubungkan antara materi yang dipelajari dengan lingkungan sekitar sehingga pada akhirnya mahasiswa memiliki kemampuan pemecahan masalah dalam kehidupan nyata. Kemampuan pemecahan masalah dalam pembelajaran juga dapat ditingkatkan dengan menggunakan thinking map. Thingking map merupakan pemetaan delapan landasan berpikir yang dapat difungsikan sebagai alat bantu untuk mengukur penguasaan suatu konsep. Berdasarkan teori ini maka dilakukan suatu penelitian kuatitatif menggunakan metode quasy experiment desain faktorial $2 \times 2$ dengan melakukan uji hipotesis. Hasil uji hipotesis dengan Anava dua jalur dan Scheefe keseluruhan diperoleh hasil bahwa nilai $\mathrm{F}$ - hitung lebih besar dibandingkan $\mathrm{F}$ - tabel sehingga dapat disimpulkan bahwa penguasaan konsep teori graf mahasiswa yang belajar dengan pendekatan kontekstual berbantuan thinking maps lebih baik daripada mahasiswa yang hanya belajar menggunakan pendekatan kontektual. Selain itu ada keterkaitan antara pendekatan kontekstual berbantuan thinking map dan kemampuan pemecahan masalah terhadap penguasaan konsep.

Kata Kunci: pendekatan kontektual, thinking maps, penguasaan konsep, pemecahan masalah 
Filda Febrinita ${ }^{[1]}$, Wahyu Dwi Puspitasari[ ${ }^{[2]}$.2018. Pengaruh Pendekatan

Kontekstual Berbantuan Thinking Map Terhadap Penguasaan Konsep Teori Graf Ditinjau dari Kemampuan Pemecahan Masalah.

Konstruktivisme, 10 (1): 98-112

\section{ABSTRACT}

Application of Graf Theory found in many activities of daily life so that students are required to be able to link the theory learned with the environment or surrounding events. Learning with contextual approach is a concept of learning that can help students to connect between the material learned with the surrounding environment so that in the end students have the ability to solve problems in real life. Problem solving skills in learning can also be improved by using the thinking map. Thingking map is a mapping of eight thinking bases that can be used as a tool to measure mastery of a concept. Based on this theory, a qualitative research is done using quasy experiment method with $2 \times 2$ factorial design by doing hypothesis test. The result of hypothesis test with two path Anava and Scheefe, obtained the result that the value of Fvalue is bigger than F-table so it can be concluded that the mastery of the concept of student graph theory that study with contextual approach with the help of maps thinking better than the students who only learn to use the approach of kontektual . In addition, there is a relationship between the context map assisted contextual approach and problem solving ability to mastery of concepts.

Keywords: contextual approach, thinking maps, conceptual mastery, problem solving

\section{PENDAHULUAN}

Pendekatan konseptual atau Contextual Teaching and Learning (CTL) merupakan konsep belajar yang dapat membantu mahasiswa untuk menghubungkan antara materi yang diajarkan dengan kejadian pada kehidupan nyata. Selain itu, pendekatan ini juga mampu mendorong mahasiswa untuk membuat keterkaitan antara pengetahuan yang dipalajari dengan penerapan pengetahuan tersebut dalam kehidupan sehari-hari (Berns \& Erickson, 2001). Dengan demikian, pembelajaran yang dilalui mahasiswa akan lebih bermakna karena materi yang dipelajari selalu berhubungan dengan situasi dan permasalahan kehidupan yang terjadi di lingkungannya.

Penerapan pendekatan kontektual dalam pembelajaran akan lebih efektif jika dibantu oleh media pembelajaran yang mendukung konsep CTL. Salah satu media yang dapat digunakan adalah thinking maps. Thinking map merupakan alat visual-verbal yang dikembangkan berdasarkan landasan kemampuan berpikir. Delapan landasan kemampuan berpikir yang digunakan 
Filda Febrinita ${ }^{[1]}$, Wahyu Dwi Puspitasari[ ${ }^{[2]}$.2018. Pengaruh Pendekatan

Kontekstual Berbantuan Thinking Map Terhadap Penguasaan Konsep Teori Graf Ditinjau dari Kemampuan Pemecahan Masalah.

Konstruktivisme, 10 (1): 98-112

meliputi kemampuan mendefinisikan, mendeskripsikan kualitas, membandingkan dan mencari persamaan, mengklasifikasi, bagian-keseluruhan, mengurutkan, sebab akibat, dan analogi (Hyerle, 2004:8). Berdasarkan penelitian Datur, Yuliati, dan Mufti (2017) pembelajaran dengan bantuan thinking map dapat meningkatkan kemampuan pemecahan masalah siswa dalam menyelesaikan soal. Sedangakan menurut Puspitasari (2014) pembelajaran dengan bantuan thinking map berpengaruh terhadap penguasaan konsep siswa.

Kemampuan pemecahan masalah merupakan salah satu tujuan utama dari pendidikan saat ini. Hal ini disebabkan, saat siswa memasuki dunia kerja mereka dituntut untuk mampu beradaptasi dan terampil dalam mengatasi kesulitan yang dihadapi (Cai, 2003a; Cai, 2003b; Meier, Hovde \& Meier, 1996). Demikian juga dalam matematika, pemecahan masalah merupakan jantung dalam pembelajaran matematika. Belajar matematika akan melatih keterampilan siswa dalam memecahkan masalah, baik permasalahan yang berhubungan dengan materi ataupun permasalahan yang terjadi dalam kehidupan sehari-hari (Kannan., dkk, 2016).

Polya mengembangkan model pemecahan masalah dalam 4 tahap, yaitu: 1) memahami masalah, 2) merancang strategi, 3) melaksanakan strategi, dan 4) melihat/meninjau kembali. Keempat tahap ini disebut sebagai keterampilan pemecahan masalah (Hardin, 2002).Selanjutnya , pada penelitian yang dilakukan oleh Silaban (2014) diperoleh hasil bahwa tedapat hubungan positif dan signifikan antara pengusaan konsep dan kemampuan pemecahan masalah. Artinya peserta didik dengan kemampuan pemecahan masalah yang baik akan memiliki penguasaan konsep yang baik juga. Berdasarkan uraian di atas, maka dalam penelitian ini, keterampilan pemecahan masalah akan digunakan untuk meninjau penguasaan konsep mahasiswa terhadap materi teori graf.

Teori graf merupakan salah satu materi dari matakuliah matematika komputasi. Graf adalah suatu diagram yang memuat informasi tertentu jika diinterpretasikan secara tepat. Graf digunakan untuk menggambarkan berbagai macam struktur yang ada. Tujuannya adalah sebagai visualisasi objek-objek agar lebih mudah dimengerti. Contoh graf yang sering dijumpai pada kehidupan sehari-hari antara lain struktur organisasi, bagan alir, peta, rangkaian listrik, dan lain-lain (Siang, 2009). 
Filda Febrinita ${ }^{[1]}$, Wahyu Dwi Puspitasari[ ${ }^{[2]}$.2018. Pengaruh Pendekatan

Kontekstual Berbantuan Thinking Map Terhadap Penguasaan Konsep Teori Graf Ditinjau dari Kemampuan Pemecahan Masalah.

Konstruktivisme, 10 (1): 98-112

Banyaknya penerapan graf dalam kehidupan menuntut mahasiswa ilmu komputer untuk mampu mengaitkan antara konsep teori graf yang dipelajari dengan penerapannya pada dunia nyata. Untuk itu, dosen harus mampu mendesain pembelajaran yang dapat mendorong siswa untuk mengaitkan teori yang dipelajari dengan lingkungan atau kejadian di sekitar. Dengan demikian, mahasiswa tidak hanya sekedar memahami teori saja tetapi juga mampu mempraktekkan keilmuannya.

Berdasarkan teori dan beberapa penelitian yang telah dilakukan dapat diambil hipotesis bahwa penguasaan konsep teori graf pada mahasiswa yang belajar dengan pendekatan kontekstual berbantuan thinking maps lebih baik daripada mahasiswa yang belajar hanya menggunakan pendekatan kontektual. Selain itu ada keterkaitan antara pendekatan kontekstual berbantuan thinking map dan kemampuan pemecahan masalah terhadap penguasaan konsep.

\section{METODE PENELITIAN}

Penelitian ini menggunakan metode quassy - experimental design dengan dua kelompok yaitu kelompok ekprimen dan kelompok kontrol. Pendekatan kontektual diterapkan pada kedua kelompok tersebut tetapi penggunaan thinking map hanya diterapkan pada kelompok ekperimen. Desain penelitian adalah faktorial $2 \times 2$ seperti pada tabel berikut.

\section{Tabel 1 Desain Penelitian 2x2 Faktorial}

\begin{tabular}{ccc}
\hline \multirow{3}{*}{$\begin{array}{c}\text { Kemampuan Pemecahan } \\
\text { Masalah }\end{array}$} & \multicolumn{2}{c}{ StrategiPembelajaran $(\mathrm{A})$} \\
\cline { 2 - 3 } & Kondekatan & Pendekatan \\
& $\left(\mathrm{A}_{1}\right)$ & Kontekstual \\
& $\mathrm{A}_{1} \mathrm{~B}_{1}$ & $\left(\mathrm{~A}_{2}\right)$ \\
\hline Tinggi $\left(\mathrm{B}_{1}\right)$ & $\mathrm{A}_{1} \mathrm{~B}_{2}$ & $\mathrm{~A}_{2} \mathrm{~B}_{1}$ \\
Rendah $\left(\mathrm{B}_{2}\right)$ & & $\mathrm{A}_{2} \mathrm{~B}_{2}$ \\
\hline & & (Sugiyono, 2010: 76)
\end{tabular}

\section{Keterangan:}

$A_{1} B_{1}$ : Siswa kelompok pemecahan masalah tinggi yang belajar dengan pendekatan kontekstual berbantuan Thinking Map.

$A_{2} B_{1}$ : Siswa kelompok pemecahan masalah tinggi yang belajar dengan pendekatan kontekstual

$A_{1} B_{2}$ : Siswa kelompok pemecahan masalah tinggi yang belajar dengan pendekatan kontekstual berbantuan Thinking Map.

$A_{2} B_{2}$ : Siswa kelompok pemecahan masalah rendah yang belajar dengan pendekatan kontekstual 
Filda Febrinita ${ }^{[1]}$, Wahyu Dwi Puspitasari[ ${ }^{[2]}$.2018. Pengaruh Pendekatan

Kontekstual Berbantuan Thinking Map Terhadap Penguasaan Konsep Teori Graf Ditinjau dari Kemampuan Pemecahan Masalah.

Konstruktivisme, 10 (1): 98-112

Variabel bebas penelitian adalah perlakuan yang diberikan berupa Pendekatan Kontekstualberbantuan Thinking Map. Variabel terikat yang menyertai penelitian ini adalah penguasaan konsep teori Graf, sedangkan variabel moderatornya adalah kemampuan pemecahan masalah.

Subyek penelitian ini melibatkan 40 mahasiswa UNISBA prodi Teknik Informatika semester I Tahun Akademik 2016/2017. Kelompok eksperimen dan kelompok kontrol ditentukan secara acak. Kelompok eksperimen adalah kelompok yang mendapatkan pembelajaran dengan Pendekatan Kontekstual berbantuan Thinking Map. Kelompok kontrol merupakan kelompok yang mendapatkan pembelajaran dengan Pendekatan Kontekstual. Jumlah mahasiswa untuk masing-masing kelompok yaitu 20.

Instrumen yang digunakan dalam penelitian ini adalah Tes Kemampuan Pemecahan Masalah dan Tes Penguasaan Konsep. Tes kemampuan pemecahan masalah yang dikembangkan merupakan tes essay, dengan didasarkan pada fase pemecahan masalah Polya, yang meliputi: (1) memahami masalah, (2) merencanakan penyelesaian, (3) menyelesaikan masalah, dan (4) refleksi. Selanjutnya, tes penguasaan konsep dikembangkan berdasarkan Taksonomi Bloom, yang meliputi domain proses kognitif C1 - C6 dan jenis tes yang digunakan adalah tes essay

Analisis data yang digunakan adalah analisis statistik deskriptif dan inferensial. Statistik deskriptif menyajikan data yang telah diperoleh ke dalam bentuk tabel yang meliputi data hasil tes kemampuan pemecahan masalah dan data hasil tes penguasaan konsep. Data yang disajikan berupa nilai minimum, maksimum, rata-rata, dan standar deviasi. Selanjutnya, statitistik inferensial digunakan untuk menentukan uji homogenitas dan uji normalitas.

Pengujian homogenitas data digunakan untuk mengetahui sebaran dari masing-masing data. Uji homogenitas yang digunakan adalah uji Bartlett seperti yang ditunjukkan pada persamaan berikut.

$$
\chi^{2}=(\ln 10)\left[B-\left(\sum d b\right) \log S_{i}{ }^{2}\right] \quad \text { (Murwani, 2001:22) }
$$

Jika $\chi^{2}$ hitung $<\chi^{2}$ tabel, maka dapat dikatakan data penguasaan konsep adalah homogen.

Sedangkan uji normalitas, bertujuan untuk mengetahui data yang diperoleh terdistribusi normal atau tidak. Uji normalitas yang digunakan dalam penelitian ini adalah uji Liliefors yang ditunjukkan pada persamaan berikut.

\section{Keterangan:}

$$
\mathrm{L}_{0}=|\mathrm{F}(\mathrm{z})-\mathrm{S}(\mathrm{z})| \quad \text { (Murwani, 2001:21) }
$$

Lo = nilai uji Liliefors 
Filda Febrinita ${ }^{[1]}$, Wahyu Dwi Puspitasari[i[2].2018. Pengaruh Pendekatan

Kontekstual Berbantuan Thinking Map Terhadap Penguasaan Konsep Teori Graf Ditinjau dari Kemampuan Pemecahan Masalah.

Konstruktivisme, 10 (1): 98-112

$\mathrm{F}(\mathrm{z}) \quad=$ besar peluang untuk masing-masing nilai $\mathrm{z}$ berdasarkan tabel $\mathrm{z}$

$\mathrm{S}(\mathrm{z}) \quad$ = frekuensi kumulatif relatif dari masing-masing nilai $\mathrm{z}$

Keputusan diambil dengan membandingkan nilai $L_{o}$ dan $L_{t}$. Apabila $L_{0}<L_{t}$ maka sampel berasal dari populasi yang berdistribusi normal. Penentuan nilai $L_{t}$ dengan $\alpha 5 \%$ dengan melihat tabel atau dihitung menggunakan persamaan berikut.

$$
\mathrm{L}_{\mathrm{t}}=\frac{0,886}{\sqrt{\mathrm{n}}} \quad \text { (Murwani, 2001: 40) }
$$

Keterangan:

Lt : nilai Liliefors dari tabel

n : banyaknya sampel

Uji hipotesis yang digunakan dalam penelitian ini adalah statistik parametrik, karena berdasarkan hasil uji prasyarat diperoleh bahwa data terdistribusi normal dan homogen. Uji statistik parametrik yang digunakan adalah uji beda ANAVA (analisis varians) dua jalur dengan mengajukan hipotesis statistik sebagai berikut.

a) Menetapkan $\mathrm{Ha}$ dan $\mathrm{Ho}$

Ho $: \mu_{1}=\mu_{2}=\ldots . .=\mu_{k}$

$\mathrm{Ha}: \mu_{1} \neq \mu_{2} \neq \ldots \mu_{\mathrm{k}}$

b) Mencari nilai $F_{\text {hitung }}$

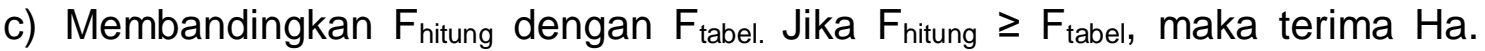
Jika $F_{\text {hitung }} \leq \mathrm{F}_{\text {tabel, }}$, maka terima $\mathrm{H}_{0}$

Apabila terjadi interaksi antar kolom dan baris dilakukan uji lanjut untuk mengetahui perbedaan mana yang signifikan dengan menggunakan uji Scheffe karena jumlah kelompok berkemampuan pemecahan masalah tinggi dan rendah tidak sama. Uji Scheffe ditunjukkan pada persamaan berikut.

$$
\mathrm{F}_{\text {hitung }}=\frac{\left(\overline{\mathrm{X}_{1}}-\overline{\mathrm{X}}_{\mathrm{j}}\right)}{\operatorname{RKD}(\mathrm{k}-1)\left[\frac{1}{\mathrm{n}_{\mathrm{i}}}+\frac{1}{\mathrm{n}_{\mathrm{j}}}\right]} \quad \text { (Murwani, 2001:6) }
$$

\section{Keterangan:}

$\mathrm{K} \quad$ : banyaknya kelompok

$X_{i} \quad$ : rata-rata kelompok ke- $i$

$X_{j} \quad$ : rata-rata kelompok ke-j

$n_{i} \quad$ : banyak data kelompok ke- $i$

$n_{j} \quad:$ banyak data kelompok ke-j

RKD : rata-rata kuadrat dalam 
Filda Febrinita ${ }^{[1]}$, Wahyu Dwi Puspitasari[ ${ }^{[2]}$.2018. Pengaruh Pendekatan

Kontekstual Berbantuan Thinking Map Terhadap Penguasaan Konsep Teori Graf Ditinjau dari Kemampuan Pemecahan Masalah.

Konstruktivisme, 10 (1): 98-112

Kriteria pengujian yaitu jika $F_{\text {hitung }}>F_{\text {tabel }}$ maka teruji bahwa $\mu_{i}>\mu_{j}$ pada taraf signifikansi $\alpha$ yang dipilih

\section{HASIL DAN BAHASAN}

Kemampuan Pemecahan Masalah

Subjek penelitian dikelompokkan menjadi dua berdasarkan nilai kemampuan pemecahan masalah. pengelompokan tersebut meliputi kelompok pemecahan masalah tinggi (PMT) dan rendah (PMR). Nilai maksimum tes kemampuan pemecahan masalah adalah 100 dan minimumnya adalah 0. Dari hasil penelitian diperoleh rata-rata kemampuan pemecahan masalah kelas Pendekatan Kontekstual berbantuan Thingking Map adalah 58 dengan standar deviasi 8,978 dan nilai minumum 39 serta maksimum 65. Untuk kelas pendekatan kontekstual memperoleh rata-rata 47 dengan standar deviasi 7,272 dan nilai minimum 35 serta maksimum 58 . Penyajian data ditunjukkan pada Tabel 1 berikut.

Tabel 2 Data Kemampuan Pemecahan Masalah Kelompok yang Belajar dengan Pendekatan Kontekstual Berbantuan Thinking Mapdan yang Belajar dengan Pendekatan Kontekstual

\begin{tabular}{lccccc}
\hline \multicolumn{1}{c}{ Kelas } & N & Mean & $\begin{array}{c}\text { Standar } \\
\text { Deviasi }\end{array}$ & Minimum & Maksimum \\
\hline Pendekatan Kontekstual & 20 & 58 & 8,978 & 39 & 65 \\
berbantuanThinking Map & 20 & 47 & 7,727 & 35 & 58 \\
Pendekatan Kontekstual & 40 & 53 & 10,090 & 35 & 70 \\
\hline Total & & & & \\
\hline
\end{tabular}

Dari Tabel 2 di atas dapat diperoleh informasi bahwa pada kelas yang pembelajarannya menggunakan pendekatan kontekstual dengan berbantuan thinking map tetap memiliki nilai minimum dan maksimum lebih tinggi dibandingkan dengan kelas yang hanya menggunakan pendekatan kontektual. Nilai minimum dan maksimum pada kelas dengan pendekatan kontekstual berbantuan thinking map adalah 39 dan 65 sedangkan pada kelas dengan pendekatan kontekstual adalah 35 dan 58 . 
Filda Febrinita ${ }^{[1]}$, Wahyu Dwi Puspitasari[i[2].2018. Pengaruh Pendekatan

Kontekstual Berbantuan Thinking Map Terhadap Penguasaan Konsep Teori Graf Ditinjau dari Kemampuan Pemecahan Masalah.

Konstruktivisme, 10 (1): 98-112

Selain pengelompokkan didasarkan pada perlakuan di kelas, pengelompokkan juga didasarkan dari kemampuan siswa dalam pemecahan masalah. Subjek penelitian dikelompokkan ke dalam dua kelompok berdasarkan hasil tes pemecahan masalah. Kelompok berkemampuan pemecahan masalah tinggi dan rendah. Selanjutnya hasil tes pemecahan masalah dari kedua kelompok dianalisis dan dideskripsikan pada Tabel 3. berikut.

Tabel 3 Data KemampuanPemecahan Masalah Tinggi dan Rendah kelompok yang Belajar dengan Pendekatan Kontekstual Berbantuan Thinking Map dan yang Belajar dengan Pendekatan Kontekstual

\begin{tabular}{|c|c|c|c|c|c|}
\hline Kelas & $\mathbf{N}$ & Mean & $\begin{array}{l}\text { Standar } \\
\text { Deviasi }\end{array}$ & Minimum & Maksimum \\
\hline $\begin{array}{l}\text { Pendekatan kontekstual +Thinking Map } \\
\text { (PMT) }\end{array}$ & $\begin{array}{l}1 \\
1\end{array}$ & 66 & 1,917 & 65 & 70 \\
\hline $\begin{array}{l}\text { Pendekatan kontekstual +Thinking Map } \\
\text { (PMR) }\end{array}$ & 9 & 52 & 7,301 & 39 & 61 \\
\hline Pendekatan kontekstual (PMT) & $\begin{array}{l}1 \\
2\end{array}$ & 55 & 3,296 & 51 & 59 \\
\hline Pendekatan kontekstual (PMR) & 8 & 40 & 9,728 & 35 & 49 \\
\hline Total & $\begin{array}{l}4 \\
0\end{array}$ & 53 & 10,090 & 35 & 70 \\
\hline
\end{tabular}

Berdasarkan Tabel 3 untuk nilai rata-rata (mean) tertinggi adalah kelompok yang belajar dengan pendekatan kontekstual berbantuan Thingking Map kelompok PMT sebesar 66 serta memperoleh nilai minimum 65 dan nilai maksimum 70. Rata-rata terendah diperoleh kelompok yang belajar dengan pendekatan kontekstual kelompok PMR sebesar 40 serta memperoleh nilai minimum 35 dan maksimm 49.

\section{Penguasaan Konsep Teori Graf}

Penguasaan konsep teori Graf memiliki nilai maksimum 100 dan nilai minimum 0. Data penguasaan konsep teori Graf kedua kelompok berdasarkan kemampuan pemecahan masalah tinggi dan rendah ditunjukkan pada Tabel 3. . 
Filda Febrinita ${ }^{[1]}$, Wahyu Dwi Puspitasari[ ${ }^{[2]}$.2018. Pengaruh Pendekatan

Kontekstual Berbantuan Thinking Map Terhadap Penguasaan Konsep Teori Graf Ditinjau dari Kemampuan Pemecahan Masalah.

Konstruktivisme, 10 (1): 98-112

Tabel 4. Data Penguasaan KonsepTeori Graf Kelompok Pemecahan Masalah Tinggi(PMT)dan Rendah (PMR) yang Belajar dengan Pendekatan Kontekstual Berbantuan ThinkingMapdan yang Belajar dengan Pendekatan Kontekstual

\begin{tabular}{|c|c|c|c|c|c|}
\hline Kelas & $\mathbf{N}$ & Mean & $\begin{array}{l}\text { Standar } \\
\text { Deviasi }\end{array}$ & Minimum & Maksimum \\
\hline $\begin{array}{l}\text { Pendekatan kontekstual +Thinking Map } \\
\text { (PMT) }\end{array}$ & $\begin{array}{l}1 \\
1\end{array}$ & 88 & 2,892 & 79 & 87 \\
\hline $\begin{array}{l}\text { Pendekatan kontekstual +Thinking Map } \\
\text { (PMR) }\end{array}$ & 9 & 78 & 1,537 & 76 & 80 \\
\hline Pendekatan kontekstual (PMT) & $\begin{array}{l}1 \\
2\end{array}$ & 74 & 2,275 & 71 & 77 \\
\hline Pendekatan kontekstual (PMR) & 8 & 71 & 1,408 & 69 & 73 \\
\hline Total & $\begin{array}{l}4 \\
0\end{array}$ & 77 & 4,938 & 69 & 87 \\
\hline
\end{tabular}

Tabel 4 merupakan hasil penguasan konsep Teori Graf stelah diberikan perlakuan. Rata-rata penguasan konsep tertinggi yaitu 88 diperoleh kelompok PMT yang belajar dengan pendekatan kontekstual berbantuan Thinking Map. Sedangkan rata-rata pengusaan konsep terendah yaitu 71 diperoleh kelompk PMR yang belajar hanya dengan pendekatan kontekstual.

\section{Deskripsi Hasil Uji Prasyarat}

Data penguasaan konsep Teori Graf sebelum dianalisis dilakukan uji prasyarat terlebih dahulu. Pengujian prasyarat meliputi uji normalitas dan homogenitas.

\section{Hasil Uji Normalitas Penguasaan Konsep Teori Graf}

Data penguasaan konsep yang diuji normalitas merupakan data yang telah dikelompokkan ke dalam kemampuan pemecahan masalah tinggi dan rendah. Hasil pengujian normalitas dengan uji Liliefors pada Tabel 5 dan Tabel 6

\section{Tabel 5 Hasil Uji Normalitas Penguasaan Konsep Kelompok Pemecahan MasalahTinggi yang Belajar dengan Pendekatan Kontekstual Berbantuan Thinking Map dan yang Belajar dengan Pendekatan Kontekstual}

\begin{tabular}{lcc}
\hline \multicolumn{1}{c}{ Kelas } & \multicolumn{2}{c}{ HasilUjiLiliefors } \\
\cline { 2 - 3 } & $\mathrm{L}_{\text {hitung }}$ & $\mathrm{L}_{\text {tabel }}$ \\
\hline Pendekatan kontekstual +Thinking Map & 0.1898 & 0.2490 \\
Pendekatan kontekstual & 0.1220 & 0.2420 \\
\hline
\end{tabular}


Filda Febrinita[1], Wahyu Dwi Puspitasari[2].2018. Pengaruh Pendekatan

Kontekstual Berbantuan Thinking Map Terhadap Penguasaan Konsep Teori Graf Ditinjau dari Kemampuan Pemecahan Masalah.

Konstruktivisme, 10 (1): 98-112

Tabel 6. Hasil Uji Normalitas Penguasaan Konsep Kelompok Pemecahan Masalah Rendah yang Belajar dengan Pendekatan Kontekstual Berbantuan Thinking Map dan yang Belajar dengan Pendekatan Kontekstual

\begin{tabular}{lcc}
\hline \multicolumn{1}{c}{ Kelas } & \multicolumn{2}{c}{ HasilUji Liliefors } \\
\cline { 2 - 3 } & Lhitung & $\mathbf{L}_{\text {tabel }}$ \\
\hline Pendekatan kontekstual +Thinking Map & 0.1375 & 0.2710 \\
Pendekatan kontekstual & 0.1715 & 0.2850 \\
\hline
\end{tabular}

Hasil pengujian Normalitas berdasarkan Tabel 5 dan Tabel 6 diperoleh bahwa untuk semua kelas, nilai Lhitunglebih kecil dari dari $L_{\text {tabel }}$ sehingga data semua kelompok terdistribusi normal. Berdasarkan hasil tersebut maka perhiungan statistik dapat dilanjutkan.

\section{Hasil Uji Homogenitas Penguasaan Konsep Teori Graf}

Selain dilakukan pengujian normalitas, data penguasaan konsep juga diuji homogenitasnya. Hasil pengujian homogenitas ditunjukkan pada Tabel 7 dan 8.

Tabel 7 Hasil Uji HomogenitasPenguasaan Konsep Kelompok Pemecahan MasalahTinggi yang Belajar dengan Pendekatan Kontekstual Berbantuan Thinking Map dan yang Belajar dengan Pendekatan Kontekstual

\begin{tabular}{ccc}
\hline \multirow{2}{*}{ KelompokUji } & \multicolumn{2}{c}{${\text { HasilUji } \chi^{2}}^{$\cline { 3 - 3 }$}$} \\
\cline { 3 - 3 } $\begin{array}{l}\text { Pendekatan kontekstual +Thinking Map } \\
\text { Pendekatan kontekstual }\end{array}$ & $\chi^{2}{ }_{\text {hitung }}$ & $\chi^{2}$ table \\
\hline
\end{tabular}

Hasil pengujian homogenitaspada tabel 7 menunjukkan bahwa penguasaan konsep kelompok PMT homogen. Hal ini dikarenakan nilai $\chi$ hitunglebih kecil daripada $\chi_{\text {tabel. }}$

Tabel 8 Hasil Uji Homogenitas Penguasaan Konsep Kelompok Pemecahan Masalah Rendah yang Belajar dengan Pendekatan Kontekstual Berbantuan Thinking Map dan yang Belajar dengan Pendekatan Kontekstual

\begin{tabular}{cccc}
\hline \multicolumn{1}{c}{ KelompokUji } & \multicolumn{2}{c}{HasilUjix $^{2}$} \\
\cline { 1 - 1 } \cline { 3 - 4 } $\begin{array}{l}\text { Pendekatan kontekstual +Thinking Map } \\
\text { Pendekatan kontekstual }\end{array}$ & & $X^{2}$ hitung & $X^{2}$ tabel \\
\hline
\end{tabular}


Filda Febrinita ${ }^{[1]}$, Wahyu Dwi Puspitasari[ ${ }^{[2]}$.2018. Pengaruh Pendekatan

Kontekstual Berbantuan Thinking Map Terhadap Penguasaan Konsep Teori Graf Ditinjau dari Kemampuan Pemecahan Masalah.

Konstruktivisme, 10 (1): 98-112

Berdasarkan uji homogenitas pada Tabel 3.7, penguasaan konsep kelompok PMR dinyatakan homogen, karena nilai $\chi$ hitunglebih kecil daripada $\chi$ tabel Deskripsi Hasil Uji Hipotesis

Ujihipotesisdilakukandenganmenggunakan persamaan uji beda rata-rata analisisvarianduajalur. HasilperhitunganditunjukkanpadaTabel 9, Tabel 10, dan Tabel 11.

Tabel 9 Hasil Uji ANAVA Dua Jalur

\begin{tabular}{lccccc}
\hline \multicolumn{1}{c}{ Sumber Varian } & \multirow{2}{*}{ Db } & \multirow{2}{*}{ JK } & \multirow{2}{*}{ RJK } & \multicolumn{2}{c}{$\mathbf{F ~ ( \alpha = 0 , 0 5 )}$} \\
\cline { 6 - 7 } & & & & $\mathbf{F}_{\text {hitung }}$ & $\mathbf{F}_{\text {tabel }}$ \\
\hline AntarStrategiPembelajaran (A) & 1 & 529,90 & 592,90 & 123,15 & 4,10 \\
AntarKemampuanPemecahan Masalah & 1 & 151,24 & 151,24 & 31,42 & 4,10 \\
(B) & & & & & \\
InteraksiKemampuan Pemecahan & 1 & 33,64 & 33,64 & 6,99 & 4,10 \\
Masalah-StrategiPembelajaran (B x A) & 36 & 173,32 & 4,81 & & \\
Dalam & 39 & 951,10 & & & \\
Total Direduksi & & & &
\end{tabular}

Tabel 3.9 Hasil Uji Penguasaan Konsep teori Graf Kelompok Berkemampuan Pemecahan Masalah Tinggi yang Belajar dengan Pendekatan Kontekstual Berbantuan Thinking Map dan yang Belajar dengan Pendekatan Kontekstual

\begin{tabular}{lccccc}
\hline \multicolumn{1}{c}{ Sumber Varian } & Db & JK & RJK & \multicolumn{2}{c}{$\mathbf{F ( \alpha = 0 , 0 5 )}$} \\
\cline { 6 - 6 } & & & & $\mathbf{F}_{\text {hitung }}$ & $\mathbf{F}_{\text {tabel }}$ \\
\hline AntarStrategi Pembelajarankelompok & & & & & \\
Kelompok Berkemampuan Pemecahan & 1 & 389,19 & 389,19 & 58,15 & 4,30 \\
MasalahTinggi & & & & & \\
$\begin{array}{l}\text { Dalam } \\
\text { Total Direduksi }\end{array}$ & 21 & 140,55 & 6,69 & & \\
\hline
\end{tabular}

Tabel 11 Hasil Uji Penguasaan Konsep Teori Graf Kelompok Berkemampuan Pemecahan Masalah Rendah yang Belajar dengan Pendekatan Kontekstual Berbantuan Thinking Map dan yang Belajar dengan Pendekatan Kontekstual

\begin{tabular}{|c|c|c|c|c|c|}
\hline \multirow{2}{*}{ Sumber Varian } & \multirow{2}{*}{$\mathrm{Db}$} & \multirow{2}{*}{ JK } & \multirow{2}{*}{ RJK } & \multicolumn{2}{|c|}{$F(\alpha=0,05)$} \\
\hline & & & & $F_{\text {hitung }}$ & $F_{\text {tabel }}$ \\
\hline $\begin{array}{l}\text { AntarStrategiPembelajaran Kelompok } \\
\text { Berkemampuan Pemecahan Masalah } \\
\text { Rendah }\end{array}$ & 1 & 237,35 & 237,35 & 108,66 & 4,49 \\
\hline Dalam & 15 & 32,76 & 2,18 & & \\
\hline Total Direduksi & 16 & 270,12 & & & \\
\hline
\end{tabular}


Filda Febrinita ${ }^{[1]}$, Wahyu Dwi Puspitasari[ ${ }^{[2]}$.2018. Pengaruh Pendekatan

Kontekstual Berbantuan Thinking Map Terhadap Penguasaan Konsep Teori Graf Ditinjau dari Kemampuan Pemecahan Masalah.

Konstruktivisme, 10 (1): 98-112

Berdasarkan hasil pengujian ANAVA dua jalur pada Tabel 3.8, Tabel 3.9 dan Tabel diperoleh nilai $F_{\text {hitung }}>F_{\text {tabel }}$ untuk semua kelompok pada taraf signifikansi 5\%. Pengujian hipotesis dengan ANAVA dua jalur menunjukkan bahwa ada perbedaan penguasaan konsep teori Graf subyek penelitian dengan kemampuan pemecahan masalah tinggi dan rendah yang belajar Pendekatan Kontekstual berbantuan thinking map dan pendekatan kontekstual. Selain itu, terdapat interaksi antara pendekatan Kontekstual berbantuan thinking map dan kemampuan pemecahan masalah terhadap penguasaaan konsep teori Graf. Selanjutnya dilakukan uji lanjut untuk mengetahui kelompok yang memiliki penguasaan konsep lebih tinggi dengan uji Scheffe.

Selanjutnya hasil pengujian dengan rumus Scheffe ditunjukkan pada Tabel 12.

\section{Tabel 12 Hasil Uji Scheffe}

\begin{tabular}{|c|c|c|}
\hline \multirow{2}{*}{ Interaksi } & \multicolumn{2}{|c|}{$F(\alpha=0,05)$} \\
\hline & $F_{\text {hitung }}$ & $F_{\text {tabel }}$ \\
\hline $\begin{array}{l}\text { Pendekatan kontekstualberbantuan ThinkingMapsPendekatan } \\
\text { Kontekstual }\end{array}$ & 123,15 & 2,86 \\
\hline $\begin{array}{l}\text { Pendekatan Kontekstualberbantuan Thinking Map } \\
\text { (PMT)vsPendekatan Kontekstual(PMT) }\end{array}$ & 58,15 & 3,13 \\
\hline $\begin{array}{l}\text { Pendekatan Kontekstual berbantuan ThinkingMap } \\
\text { (PMR)vsPendekatan Kontekstual(PMR) }\end{array}$ & 15,82 & 2,78 \\
\hline
\end{tabular}

Hasil pengujian Schefee pada Tabel 12 menunjukkan bahwa penguasaan konsep kelompok dengan kemampuan pemecahan masalah tinggi dan rendah yang belajar pendekatan kontekstual berbantuan thinking map lebih tinggi dibandingkan kelompok yang belajar dengan pendekatan kontekstual. Penjabaran lebih lanjut hasil tiap hipotesis sebagai berikut.

a. BerdasarkanTabel 3.8 dan Tabel 10 dapat disimpulkan bahwa terdapat perbedaan penguasaan konsep antara kelompok kemampuan pemecahan masalah tinggi yang belajar pendekatan kontekstual berbantuan Thinking Map dan yang belajar pendekatan kontesktual. Hasil uji lanjut pada Tabel 12 menunjukkan bahwa penguasaan konsep kelompok kemampuan pemecahan masalah tinggi yang belajar pendekatan kontekstual berbantuan Thinking Map lebih tinggi dibandingkan kelopok yang belajar pendekatan kontekstual.

b. Berdasarkan hasil yang diperoleh pada Tabel 9 dan Tabel 10 dapat disimpulkan bahwa terdapat perbedaan penguasaan konsep antar kelompok pemecahan masalah rendah yang belajar pendekatan kontekstual berbantuan Thinking Map dan kelompok yang belajar pendekatan kontekstual. Hasil uji lanjut terdapat pada Tabel 12 menunjukkan bahwa 
Filda Febrinita ${ }^{[1]}$, Wahyu Dwi Puspitasari[ ${ }^{[2]}$.2018. Pengaruh Pendekatan

Kontekstual Berbantuan Thinking Map Terhadap Penguasaan Konsep Teori Graf Ditinjau dari Kemampuan Pemecahan Masalah.

Konstruktivisme, 10 (1): 98-112

penguasaan konsep kelompok pemecahan masalah rendah yang belajar pendekatan kontekstual berbantuan Thinking Map lebih tinggi dibandingkan kelompok yang belajar pendekatan kontekstual.

c. Tabel 9 menunjukkan adanya interaksi yang terjadi antara pendekatan kontekstual berbantuan thinking map dan kemampuan pemecahan masalah terhadap penguasaan konsep.

\section{Kesimpulan}

Berdasarkan paparan hasil dan pembahasan penelitian maka kesimpulan dari penelitian ini adalah sebagai berikut.

1. Penguasaan konsep teori graf pada mahasiswa kelompok kemampuan pemecahan masalah tinggi yang belajar dengan pendekatan kontekstual berbantuan thinking map dibandingkan dengan mahasiswa yang hanya belajar dengan pendekatan kontekstual, menunjukkan adanya perbedaan yang signifikan dengan nilai $F_{\text {hitung }}=53,15>F_{\text {tabel }}=4$,30pada taraf signifikansi $5 \%$. Mahasiswa kelompok kemampuan pemecahan masalah tinggi yang belajar dengan pendekatan kontekstual berbantuan thinking map menunjukkan penguasaan konsep lebih tinggi daripada mahasiswa yang hanya belajar dengan pendekatan kontekstual

2. Penguasaan konsep teori graf pada mahasiswa kelompok kemampuan pemecahan masalah rendah yang belajar dengan pendekatan kontekstual berbantuan thinking map dibandingkan dengan mahasiswa yang hanya belajar dengan pendekatan kontekstual, menunjukkan adanya perbedaan yang signifikan. Hal ini ditunjukkan dari nilai $F_{\text {hitung hasil pengujian }}$ dibandingkan dengan $F_{\text {tabel. }}$. Nilai $F_{\text {hitung yang diperoleh adalah 108,66 lebih }}$ besar dari $F_{\text {tabel }} 4,49$. Mahasiswa kelompok kemampuan pemecahan masalah rendah yang belajar dengan pendekatan kontekstual berbantuan thinking map menunjukkan penguasaan konsep lebih tinggi daripada mahasiswa yang hanya belajar dengan pendekatan kontekstual

3. Terdapat interaksi antara pendekatan kontekstual berbantuan thinking map dan kemampuan pemecahan masalah terhadap penguasaan konsep teori graf berdasarkan uji ANAVA dua jalur. Hasil pengujian ANAVA dua jalur

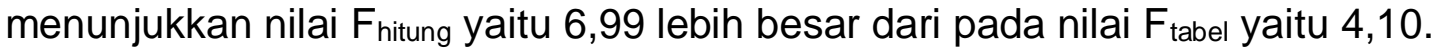
Thinking map menyajikan cara belajar yang berbeda pada mahasiswa sehingga otak memberikan perhatian lebih yang berdampak pada daya ingat. 
Filda Febrinita ${ }^{[1]}$, Wahyu Dwi Puspitasari[ ${ }^{[2]}$.2018. Pengaruh Pendekatan

Kontekstual Berbantuan Thinking Map Terhadap Penguasaan Konsep Teori Graf Ditinjau dari Kemampuan Pemecahan Masalah.

Konstruktivisme, 10 (1): 98-112

Selain itu, dengan melatih kemampuan pemecahan masalah, penguasaan

konsep pada materi yang dipelajari akan lebih maksimal.

\section{Saran}

Penelitian ini sebaiknya juga dilakukan pada matakuliah bidang teknik informatika yang lain, mengingat banyak mahasiswa yang pada kenyataannya sulit untuk mengkaitkan dan menerapkan teori yang dipelajari dengan persamalahan kehidupan sehari-hari. Selain itu, sebaiknya pendekatan konstektual ini dicoba untuk dikombinasikan dengan metode atau strategi pembelajaran lain yang juga dapat meningkatkan pemahaman konsep mahasiswa sehingga diharapkan akan muncul model pembelajaran baru yang lebih efektif dan tepat guna, baik bagi dosen ataupun mahasiswa.

\section{RUJUKAN}

Berns, R.G., \& Erickson, P.M. 2001. Contextual Teaching and Learning: Preparing Students for the New Economy. Online. The Highlight Zone: Research @ Work No. 5, 2001. http://www.nccte.com/publications/infosynthesis/index.asp\#HZ)

Cai, J. 2003a. Singaporean students' mathematical thinking in problem solving and problem posing: An exploratory study. International Journal of Mathematical Education in Science and Technology, 34(5), 719-737.

Cai, J. 2003b. What research tells us about teaching mathematics through problem solving. In K. Frank \& D. Lester (Eds.), Teaching mathematics through problem solving prekindergarten-Grade 6. Reston, VA: National Council of Teachers of Mathematics Publications.

Datur, I.S., Yuliati, L., \& Mufti, N. (2017). Kemampuan Pemecahan Masalah Materi Fluida Statis Melalui Pembalajaran Berbasis Masalah Berbantuan Thingking Map. Jurnal Inspirasi Pendidikan, 7 (2): 118 - 127.

Hardin, L.E. 2002. Problem Solving Concepts and Theories. JVME 30(3) AAVMC http://www.utpjournals.com/jvme/tocs/303/226.pdf. 
Filda Febrinita ${ }^{[1]}$, Wahyu Dwi Puspitasari[i[2].2018. Pengaruh Pendekatan

Kontekstual Berbantuan Thinking Map Terhadap Penguasaan Konsep Teori Graf Ditinjau dari Kemampuan Pemecahan Masalah.

Konstruktivisme, 10 (1): 98-112

Hyerle, D. 2004. Transformation Language for Learning. North America: Corwin Press.

Kannan, S., Sivapragasam., \& Senthilkumar. 2016. A Study on Problem Solving Ability in Mathematics of IX Standard Students in Dindigul District. International Journal of Applied Research. 2(1):797 - 799 ISSN Print: 2394-7500 ISSN Online: 2394-5869

Meier, S. L., Hovde, R. L. \& Meier, R. L. (1996). Problem solving: Teachers' perceptions, content area models, and interdisciplinary connections. School Scence and Mathematics, 96(5), 230-237.

Murwani, S. 2001. Statistika Terapan (Teknik Analisis Data). Program Pascasarjana Universitas Negeri Jakarta

Puspitasari, W., D.2014.PengaruhStrategi Brain Based LearningBerbantuan Thinking Map terhadapPenguasaanKonsepFisikaDitinjau dari Kemampuan Berpikir Kritis Siswa SMA. Tesis, Pascasarjana. Malang: Universitas Negeri Malang.

Siang, Jong Jek. 2009. Matematika Diskrit dan Aplikasinya pada IImu Komputer. Yogyakarta : ANDI

Silaban, B. 2014. Hubungan Antara Penguasaan Konsep Fisika dan Kreativitas dengan Kemampuan Memecahkan Masalah pada Materi Pokok Listrik Statis. Jurnal Penelitian Bidang Pendidikan, 20 (1): 65 - 75.

Sugiyono. 2010. Statistika untuk Penelitian. Bandung : Alfabeta 